\title{
Spectrum and Prevalence of GIT Admissions at a Tertiary Hospital in a Resource Poor Setting, Northwestern Nigeria: A Five Year Review
}

\author{
A. Yakubu, S.A. Maiyaki, A.A. Musa, A. Sakajiki, H. Umar
}

\begin{abstract}
Background:Gastrointestinal tract diseases cause a significant global health problem, approximately accounts for 8 million deaths per year worldwide. This study aims to describe the pattern of Gastrointestinal (GIT) disease cases seen at thein-service medical wards of the Usmanu Danfodiyo University Teaching Hospital (UDUTH), Sokoto, Nigeria.
\end{abstract}

Materials and Methods: A retrospective hospital-based review of GIT admission obtained from $1^{\text {st }}$ January 2013 to $31^{\text {st }}$ of December 2017 in the Department of Internal Medicine of Usmanu Danfodiyo University Teaching Hospital Sokoto state Nigeria. The hospital draws its patients from Sokoto and neighboring Kebbi, Zamfara, Katsina and Niger states. Data were extracted from patients' case folders. The data were validated using Microsoft excel version 13 and exported to SPSS version 23.0 (Chicago IL) for windows; for statistical analysis.

Result:There were a total of 1266 GIT patients admitted during the study period, $688(54.3 \%)$ were males, and $578(45.7 \%)$ were females, with a male to female ratio of 1.2:1. The mean age of the study participants was 39.4 with $\mathrm{SD} \pm 18.4$ and the age range of $1-100$ years respectively. The peak age incidence occurred within third-fifth decade accounted for 764(64\%) The result indicated that age was found to be a significant factor in association with GIT disorders $\left(X^{2}=481.1\right.$, $\mathrm{DF}=152, \quad \mathrm{P}<0.05)$.

Conclusion: Determination of the various GI disease conditions and the factors responsible for variability in incidence and outcomes of diseases will allow clinicians, public health professionals, policymakers, and healthcare organizations to intervene in a more scientifically logical way thereby ensuring effective resource allocation to decrease the overall burden of gastrointestinal disease.

Index Terms - Gastrointestinal, GIT, gastrointestinal disease.

\section{INTRODUCTION}

Gastrointestinal diseases refer to the diseases involving the mouth,esophagus, stomach, small intestine, large intestine, rectum and the accessory organs of digestion, the liver, gallbladder, and pancreas[1].The gastrointestinal system can be affected by various disease conditions which could be infectious, genetic, autoimmune or neoplastic and these disease conditions can present acutely or insidiously[2, $\underline{3}]$. Gastrointestinal diseases cause a significant global health problem, approximately accounting for 8 million deaths per year worldwide[4].Published data are scarce on time trends of gastrointestinal disease in Africa.[5-8]. Most mortality reviews in Nigeria emanated from the south-west [9-13].

Diarrheal disease is the second leading cause of mortality worldwide with an estimated 2.5 billion cases of diarrheaoccurring annually in children under five years of age, nearly one in five child deaths (about 1.5 million)each year is due to diarrheal diseases[14].

Liver disease, one of the gastrointestinal diseases accounts for approximately 2 million deaths per year worldwide, one million due to complications of cirrhosis and one million due to viral hepatitis and hepatocellular carcinoma[15]. Cirrhosis is currently the $11^{\text {th }}$ most common cause of death globally and liver cancer is the $16^{\text {th }}$ leading cause of death; combined, they account for $3.5 \%$ of all deaths worldwide. Cirrhosis is within the top 20 causes of disability-adjusted life years and years of life lost and account for $1.6 \%$ and $2.1 \%$ of the worldwide burden[15]

The study aimed at determining the various types of gastrointestinal diseases commonly seen in our environment. It has the potential to positively influence theplanning of preventive and curative measures as well as educating inhabitants appropriately as a way to reduce the morbidity and mortality associated with the disease conditions.

\section{MATERIALS AND MethoD}

A retrospective hospital-based review of GIT admission obtained from $1^{\text {st }}$ January 2013 to $31^{\text {st }}$ of December 2017 in the Department of Internal medicine of Usmanu Danfodiyo University Teaching Hospital Sokoto state Nigeria. Data were extracted from patients' case folders. The data were validated using Microsoft excel version 13 and exported it into SPSS version 23.0 (Chicago IL) for windows; for statistical analysis. The data were analyzed for demographic and other clinical characteristics as categorical variables. 
Mean and the standard deviation were determined for quantitative variables. All variables were coded as binary dummy variables. For example gender (males $=1$, females $=$ 2 ), and so on. Data were presented as frequency distribution and charts generated for all categorical variables, while Mean and standard deviation were determined for a quantitative variable. Descriptive and inferential statistics (Chi-square Fisher exact test) was applied between demographic, clinical presentation (Independent variables) and GIT cases (dependent variables) $\mathrm{P} \leq 0.05$ is considered as statistically significant.

\section{RESULTS}

A total of 1266 GIT patients admitted during the study period, 688(54.3\%) were males, and 578(45.7\%) were females, with a male to female ratio of $1.2: 1$. The mean age of the study participants was 39.4 with $\mathrm{SD} \pm 18.4$ and the age range of 1-100 years respectively. The peak age incidence occurred within third-fifth decade accounted for 764(64\%) see figure 2. Majority of the patients were Hausa/Fulani by tribe consisting of $1133(89.5 \%), 35(2.8 \%)$ Yoruba, $32(2.53 \%)$ Igbo and other tribes accounted for $66(5.21 \%)$ figure 3. The proportion of various sources of admission as shown in Table indicate that the majority of patients [921(72.7\%)] were admitted through Accident and Emergency while 94(7.4\%) were from Medical outpatient department. Figure 4 indicates the annual trend of GIT cases by gender; 2013 had the highest record of admission 293 cases. Of these admissions, 167(13.19\%)were male while $117(9.24 \%)$ were female. In 2014 the admission rate recorded was 261 where females $144(11.37 \%$ ) were higher than males $117(9.24 \%)$. Table 2 illustrates the distribution of the top ten GIT diseases as seen on the medical wards of UDUTH. Three hundred and eighty-five $(30 \%)$ cases were due to chronic liver diseases, 370(29.2\%) were due to Dyspepsia, 240(19\%) due to Diarrheal diseases, 61(4.8\%) abdominal Tuberculosis(TB), 58(4.6\%) Intra-abdominal malignancies,47(3.7\%) Acute cholecystitis, 22(1.7\%) Human Immunodeficiency Virus/Acquired Immunodeficiency syndrome (HIV/AIDS), 21(1.7\%) Septiecaemia, 11(0.9\%) Acute viral hepatitis and Upper GI bleeding accounted for 10(0.8\%). Four hundred and eighty-four (38.2\%) patientsdeveloped complications during admission. These complications were grouped according to the systems involved. One hundred and sixty-three (12.9\%) patients developed Gastrointestinal (GIT) complications. Hematemesis accounted for 150(11.8\%), Neuropsychiatric [(predominantly hepatic encephalopathy) 72(5.7\%)]. See table 3. The frequency of the outcomes of the study participants was depicted in table 4. A total of $811(64 \%)$ were formally discharged, of these Five hundredand twenty-six $(41.5 \%)$ patients completely recovered at the end ofhospitalization, 247(19.5\%) were stable and 38(3\%) were improved. Deaths on admission accounted for 236(18.6\%), $199(15.7 \%)$ signed against medical advice, 13(1\%) absconded while $7(0.6 \%)$ were transferred to other units for further treatment. Table 5 shows the cross-tabulation of GIT disease and age categories of patients; the majority of chronic liver diseases occurred within the age group of 31-34 and 41-50 years which accounted for 185(48\%), while Dyspepsia182 (49\%) was observed higher within the age range of 21-30 and 31-40 years. Age was found to be a significant factor in GIT disorders $\left(\mathrm{X}^{2}=481.1\right.$, DF $=$ 152, $\mathrm{P}<0.05)$. A correlation chart as illustrated in figure 4 , indicates that the distribution clinical outcome significantly varied between male and female $(\mathrm{P}<0.05)$. Among 688 participants, $169(24.6 \%)$ mortalities were male while out of 578 females $67(11.6 \%)$ died. Majority of the discharged patients 289(50.0\%) were females while the males constituted 237(34.4\%). Contingency table 6 Shows the distribution of GIT versus gender; among 385 chronic liver disease cases $310(80.5 \%$ ) were male, $75(19.5 \%$ ) were female out of 370 dyspeptic patients females had the highest proportion 227(61.40) when compared to male 143(61.4\%). Based on the result obtained there was a statistically significant association between GIT cases and gender $\left(\mathrm{X}^{2}=\right.$ 185.308, Df $=19, \quad \mathrm{P}<0.05)$. Three hundred and eighty-five patients diagnosed with chronic liver disease, the mortality cases accounted for $147(38.2 \%)$, 3(0.80\%) absconded, $103(26.8 \%)$ were discharged, 4(1\%) improved, 79(20.5\%) signed against medical advice, $47(12.2 \%)$ were stable at discharge while $2(0.5 \%)$ were transferred to other services.See table 7 


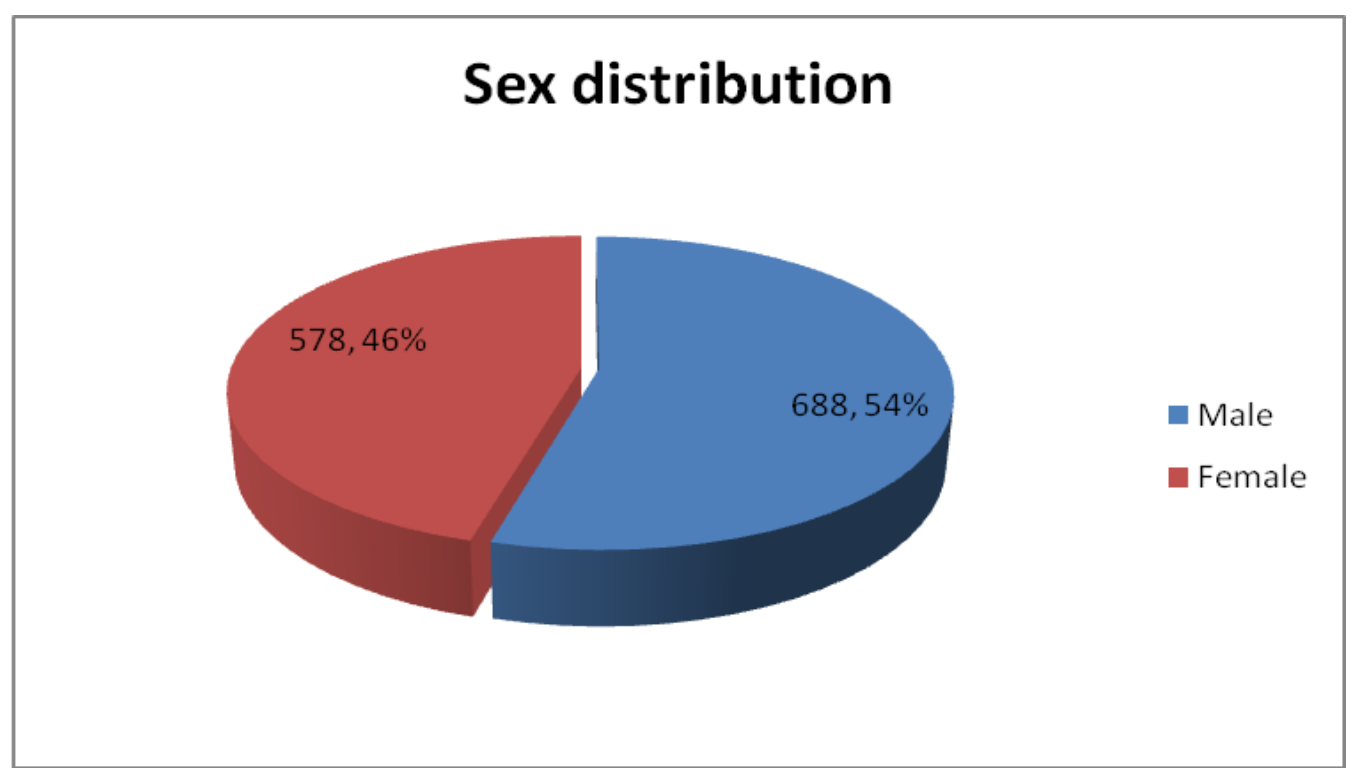

Figure 1: Sex distribution of study participants

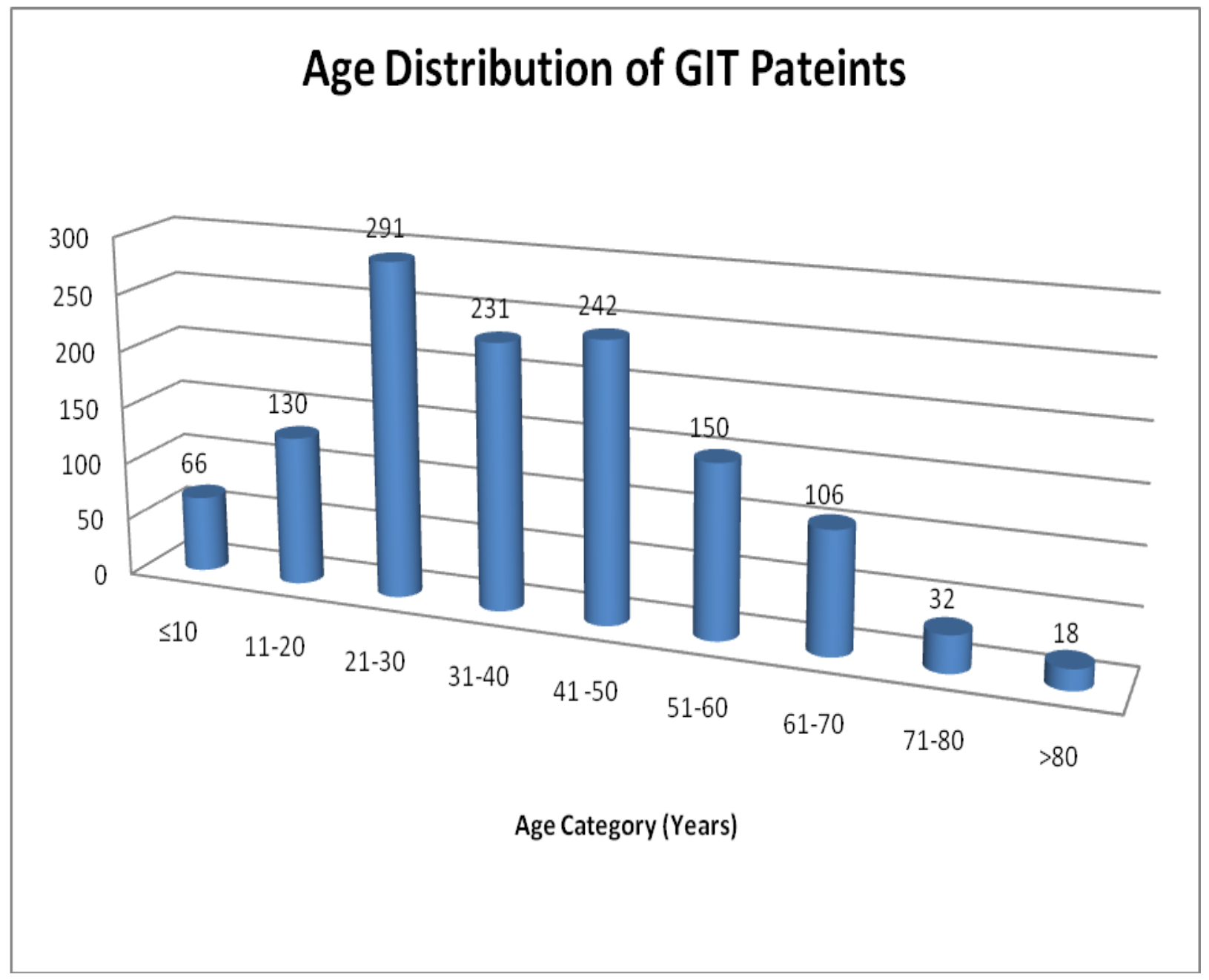

Figure 2: Age distribution of the participants 
Spectrum and Prevalence of GIT Admissions at a Tertiary Hospital in a Resource Poor Setting, Northwestern Nigeria: A Five Year Review

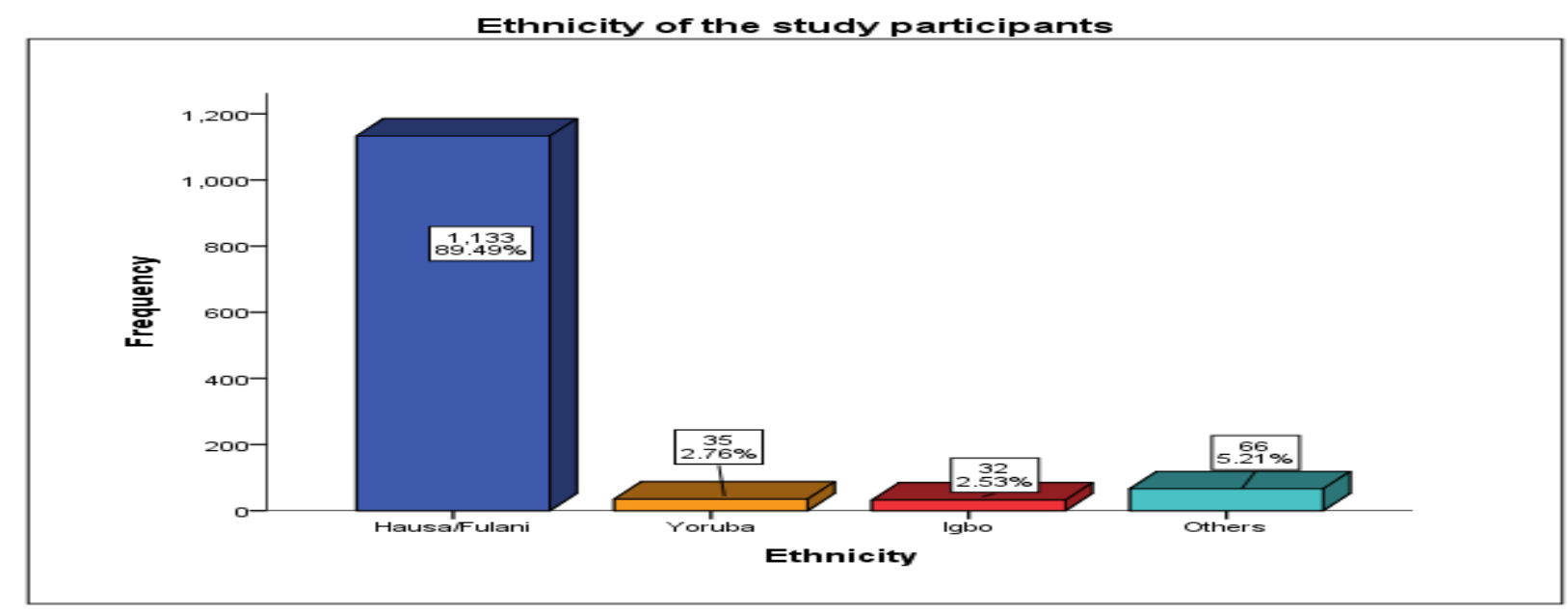

Figure 3: Ethnicity of the participants

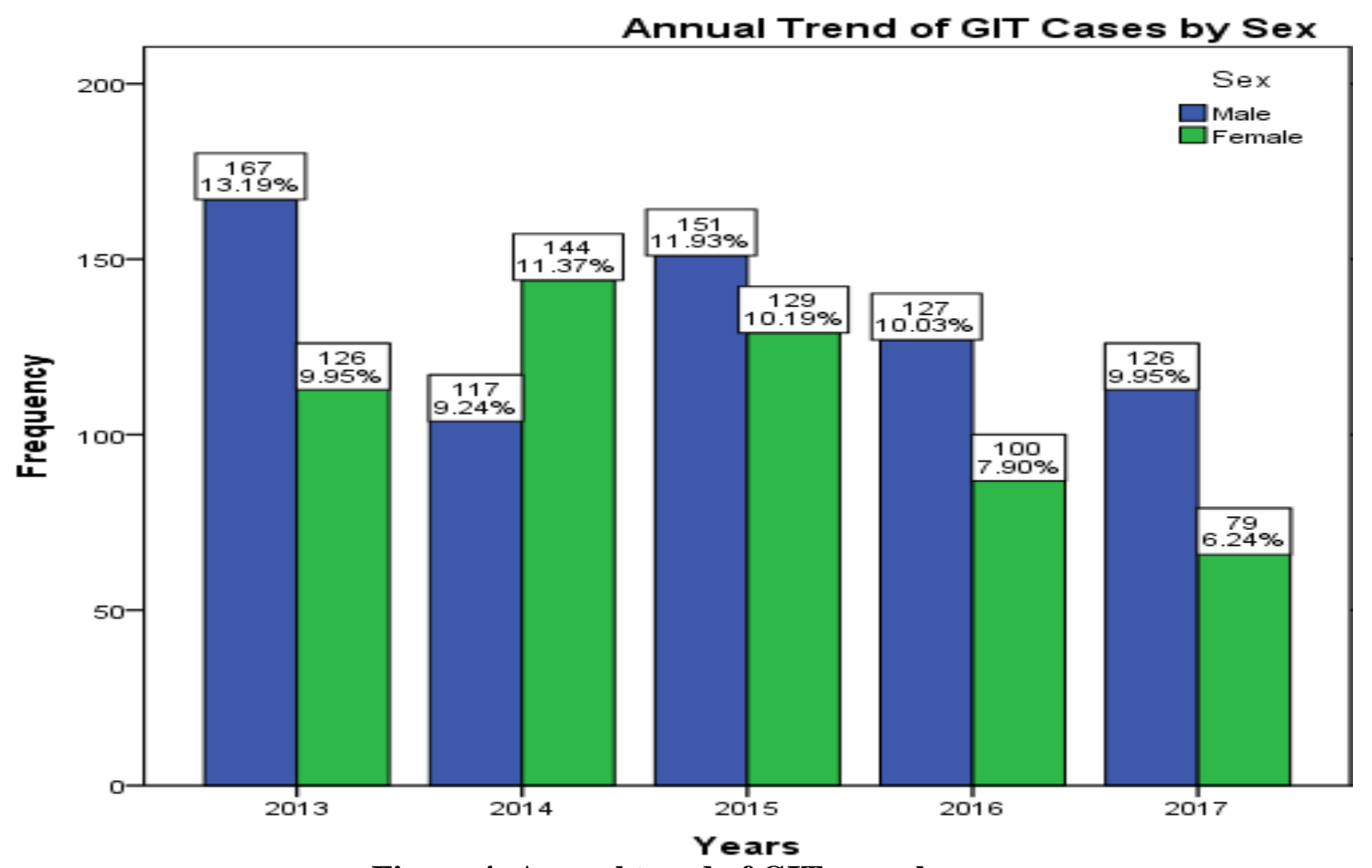

Figure 4: Annual trend of GIT cases by sex 


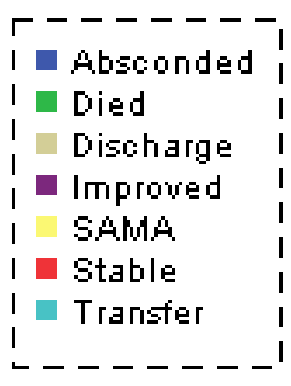

Dut Come

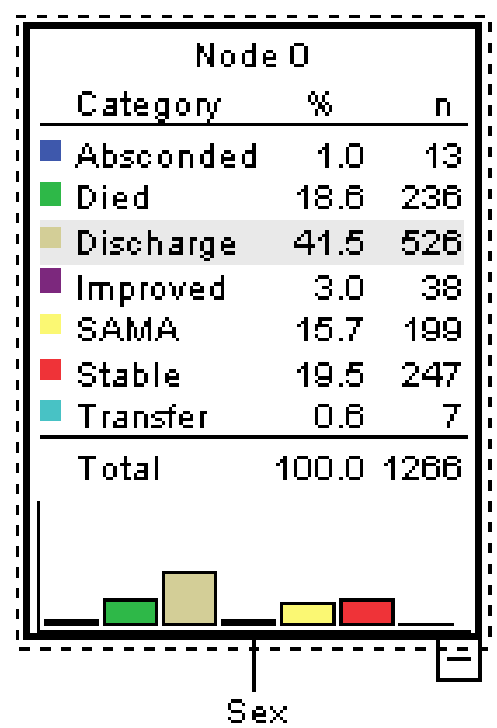

Adj. P-value=0.000, Chi-square=94.180.

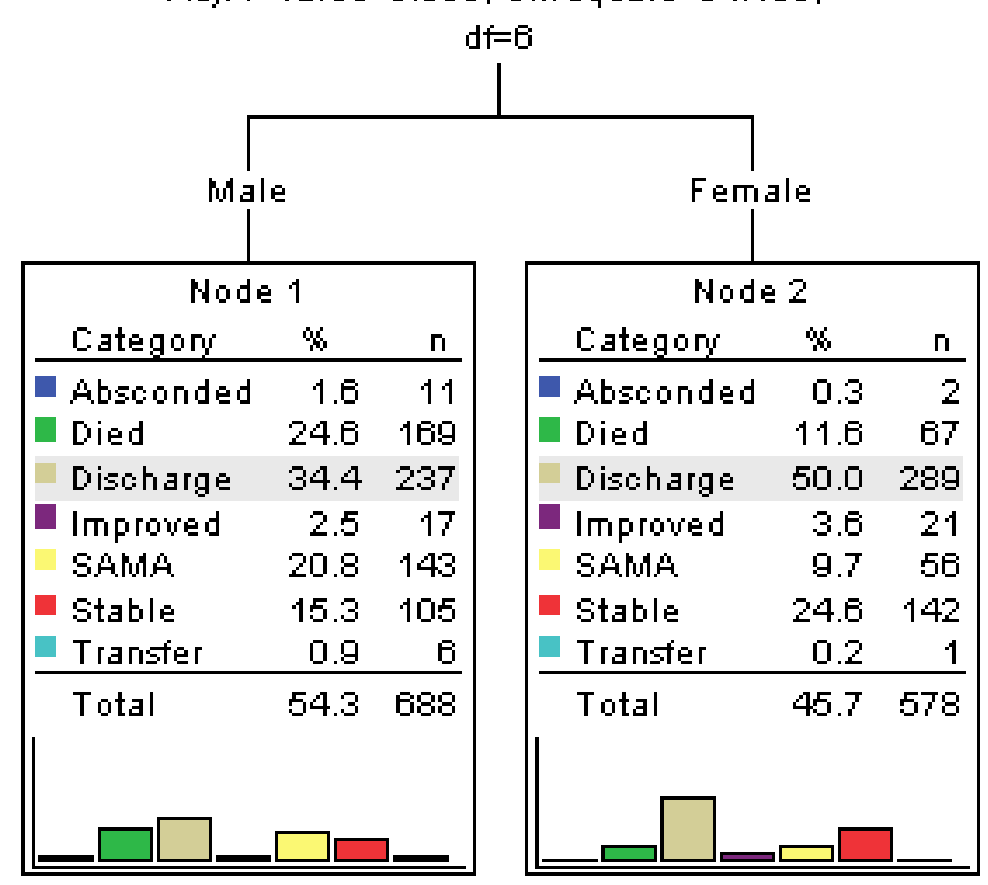

Figure 5: Correlation chart between Independent variable (gender) and dependent variable( Outcome)

Table 1: Source of Admission of GIT patients

\begin{tabular}{|l|l|l|}
\hline Sources & Frequency & Percent \\
\hline A\&E & 921 & 72.7 \\
\hline MOPD & 94 & 7.4 \\
\hline CSO & 78 & 6.2 \\
\hline EPU & 64 & 5.1 \\
\hline SOPD & 56 & 4.4 \\
\hline GEC & 27 & 2.1 \\
\hline
\end{tabular}


Spectrum and Prevalence of GIT Admissions at a Tertiary Hospital in a Resource Poor Setting, Northwestern Nigeria: A Five Year Review

\begin{tabular}{|l|l|l|}
\hline GYNAE & 18 & 1.4 \\
\hline GOPD & 5 & 0.4 \\
\hline CTU & 1 & 0.1 \\
\hline ENT & 1 & 0.1 \\
\hline POPD & 1 & 0.1 \\
\hline Total & 1266 & 100 \\
\hline
\end{tabular}

$\mathrm{A} \& \mathrm{E}=$ Accident and Emergency, EPU =Emergency Paediatric Unit, SOPD $=$ Surgical Out Patients Department, GEC $=$, GYNAE = Gynaecology Emergency Clinic GOPD= General Out Patients Department, CTU = Cardiothoracic Unit, ENT= Ear nose and throat, $\mathrm{POPD}=$ Paediatric Out Patient Department

Table 2: Distribution of Top Ten Gastrointestinal tract disorders

\begin{tabular}{|l|l|l|}
\hline Diagnosis & Frequency & Percent \\
\hline Chronic Liver Disease & 385 & 30.4 \\
\hline Dyspepsia & 370 & 29.2 \\
\hline Diarrheal disease & 259 & 20.5 \\
\hline Abdominal Tuberculosis (TB) & 61 & 4.8 \\
\hline Intra-abdominal malignancies & 58 & 4.6 \\
\hline Acute cholecystitis & 47 & 3.7 \\
\hline HIV/AIDS & 22 & 1.7 \\
\hline Septicemia & 21 & 1.7 \\
\hline Acute viral hepatitis & 11 & 0.9 \\
\hline Upper GI bleeding & 10 & 0.8 \\
\hline
\end{tabular}

Table 3: Complication presented by the study participant

\begin{tabular}{|l|l|l|}
\hline Complication & Frequency & Percent \\
\hline None & 782 & 61.8 \\
\hline GIT & 163 & 12.9 \\
\hline Hematemesis & 150 & 11.8 \\
\hline NeuroPsychiatric & 72 & 5.7 \\
\hline Genitourinary/Renal & 67 & 5.3 \\
\hline Cardiovascular & 16 & 1.3 \\
\hline Endocrine & 10 & 0.8 \\
\hline Infectious Diseases. & 5 & 0.4 \\
\hline Musculoskeletal & 1 & 0.1 \\
\hline Total & 1266 & 100 \\
\hline
\end{tabular}

Table 4: Clinical Outcome of the study participants

\begin{tabular}{|l|l|l|}
\hline Outcome & Frequency & Percent \\
\hline Discharged & 526 & 41.5 \\
\hline Stable & 247 & 19.5 \\
\hline Died & 236 & 18.6 \\
\hline SAMA & 199 & 15.7 \\
\hline Improved & 38 & 3 \\
\hline
\end{tabular}




\begin{tabular}{|l|l|l|}
\hline Absconded & 13 & 1 \\
\hline Transfer & 7 & 0.6 \\
\hline Total & 1266 & 100 \\
\hline
\end{tabular}

Table 5: Age distribution versus GIT diseases

\begin{tabular}{|c|c|c|c|c|c|c|c|c|c|c|}
\hline Diagnosis & $\leq 10$ & $11-20$ & $21-30$ & $31-40$ & $41-50$ & $51-60$ & $61-70$ & $71-80$ & $>80$ & Tota \\
\hline $\begin{array}{l}\text { Chronic Liver } \\
\text { Disease }\end{array}$ & 0 & $17(4.40 \%)$ & $54(14.00 \%)$ & $\begin{array}{l}84(21.80 \% \\
)^{2}\end{array}$ & $\begin{array}{l}101(26.20 \% \\
)\end{array}$ & $\begin{array}{l}63(16.40 \% \\
)^{2}\end{array}$ & $\begin{array}{l}48(12.50 \% \\
)\end{array}$ & $\begin{array}{l}12(3.10 \% \\
\end{array}$ & $6(1.60 \%)$ & 385 \\
\hline Dyspepsia & $3(0.80 \%)$ & $\begin{array}{l}47(12.70 \% \\
)\end{array}$ & $\begin{array}{l}107(28.90 \% \\
)\end{array}$ & $\begin{array}{l}75(20.30 \% \\
)\end{array}$ & $72(19.50 \%)$ & $\begin{array}{l}38(10.30 \% \\
)\end{array}$ & $21(5.70 \%)$ & $6(1.60 \%)$ & $1(0.30 \%)$ & 370 \\
\hline Diarrheal disease & $13(5.00 \%)$ & $\begin{array}{l}36(13.90 \% \\
)\end{array}$ & $75(29.00 \%)$ & $\begin{array}{l}29(11.20 \% \\
{ }^{2}\end{array}$ & $38(14.70 \%)$ & $29(11.20 \%$ & $24(9.30 \%)$ & $9(3.50 \%)$ & $6(2.30 \%)$ & 259 \\
\hline Abdominal TB & $\begin{array}{l}16(26.20 \% \\
)\end{array}$ & $\begin{array}{l}15(24.60 \% \\
)\end{array}$ & $5(8.20 \%)$ & $9(14.80 \%)$ & $6(9.80 \%)$ & $5(8.20 \%)$ & $3(4.90 \%)$ & $2(3.30 \%)$ & 0 & 61 \\
\hline $\begin{array}{l}\text { Intra-abdominal } \\
\text { malignancies }\end{array}$ & $3(5.10 \%)$ & $5(8.50 \%)$ & $8(13.60 \%)$ & $\begin{array}{l}13(22.00 \% \\
)\end{array}$ & $13(22.00 \%)$ & $9(15.30 \%)$ & $5(8.50 \%)$ & $2(3.40 \%)$ & $1(1.70 \%)$ & 59 \\
\hline Acute cholecystitis & $\begin{array}{l}19(40.40 \% \\
)\end{array}$ & $5(10.60 \%)$ & $9(19.10 \%)$ & $6(12.80 \%)$ & $4(8.50 \%)$ & 0 & $3(6.40 \%)$ & 0 & $1(2.10 \%)$ & 47 \\
\hline RVD(HIV/AIDS) & 0 & $1(4.50 \%)$ & $11(50.00 \%)$ & $6(27.30 \%)$ & $4(18.20 \%)$ & 0 & 0 & 0 & 0 & 22 \\
\hline Septiecaemia & $5(23.80 \%)$ & $1(4.80 \%)$ & $7(33.30 \%)$ & $1(4.80 \%)$ & $2(9.50 \%)$ & $3(14.30 \%)$ & $1(4.80 \%)$ & 0 & $1(4.80 \%)$ & 21 \\
\hline
\end{tabular}

Table 6: Top Ten Sex distribution by GIT cases

\begin{tabular}{|l|l|l|l|l|}
\hline Diagnosis & & Male & Female & Total \\
\hline Abdominal TB & Count & 31 & 30 & 61 \\
\cline { 2 - 5 } & Percent & $50.80 \%$ & $49.20 \%$ & $100.00 \%$ \\
\hline \multirow{2}{*}{ Dyspepsia } & Count & 143 & 227 & 370 \\
\cline { 2 - 5 } & Percent & $38.60 \%$ & $61.40 \%$ & $100.00 \%$ \\
\hline \multirow{2}{*}{ Acute cholecystitis } & Count & 26 & 21 & 47 \\
\cline { 2 - 5 } & Percent & $55.30 \%$ & $44.70 \%$ & $100.00 \%$ \\
\hline Intra-abdominal malignancies & Count & 9 & 2 & 11 \\
\cline { 2 - 5 } & Percent & $81.80 \%$ & $18.20 \%$ & $100.00 \%$ \\
\hline Chronic Liver Disease & Count & 32 & 27 & 59 \\
\cline { 2 - 5 } & Percent & $54.20 \%$ & $45.80 \%$ & $100.00 \%$ \\
\hline Diarrheal disease & Count & 310 & 75 & 385 \\
\cline { 2 - 5 } & Percent & $80.50 \%$ & $19.50 \%$ & $100.00 \%$ \\
\hline HIV/AIDS & Count & 110 & 149 & 259 \\
\cline { 2 - 5 } & Percent & $42.50 \%$ & $57.50 \%$ & $100.00 \%$ \\
\hline Septicemia & Count & 8 & 14 & 22 \\
\cline { 2 - 5 } & Percent & $36.40 \%$ & $63.60 \%$ & $100.00 \%$ \\
\hline Upper GI bleeding & Count & 11 & 10 & 21 \\
\cline { 2 - 5 } & Percent & $52.40 \%$ & $47.60 \%$ & $100.00 \%$ \\
\hline Chi-square & Count & 2 & 8 & 10 \\
\cline { 2 - 5 } & Percent & $20.00 \%$ & $80.00 \%$ & $100.00 \%$ \\
\hline
\end{tabular}

Table 7: Distribution of clinical outcome versus GIT Disorders

\begin{tabular}{|l|l|l|l|l|l|l|l|l|l|}
\hline GIT Diseases Types & & Absconded & Died & Discharged & Improved & SAMA & Stable & Transfer & Total \\
\hline \multirow{2}{*}{$\begin{array}{l}\text { Abdominal } \\
\text { Tuberculosis (TB) }\end{array}$} & Count & 1 & 6 & 12 & 1 & 25 & 16 & 0 & 61 \\
\cline { 2 - 10 } & Percent & $1.60 \%$ & $9.80 \%$ & $19.70 \%$ & $1.60 \%$ & $41.00 \%$ & $26.20 \%$ & $0.00 \%$ & $100.00 \%$ \\
\hline
\end{tabular}


Spectrum and Prevalence of GIT Admissions at a Tertiary Hospital in a Resource Poor Setting, Northwestern Nigeria: A Five Year Review

\begin{tabular}{|c|c|c|c|c|c|c|c|c|c|}
\hline \multirow[t]{2}{*}{ Dyspepsia } & Count & 1 & 14 & 197 & 16 & 40 & 100 & 2 & 370 \\
\hline & Percent & $0.30 \%$ & $3.80 \%$ & $53.20 \%$ & $4.30 \%$ & $10.80 \%$ & $27.00 \%$ & $0.50 \%$ & $100.00 \%$ \\
\hline \multirow[t]{2}{*}{ Acute cholecystitis } & Count & 1 & 7 & 23 & 0 & 4 & 10 & 2 & 47 \\
\hline & Percent & $2.10 \%$ & $14.90 \%$ & $48.90 \%$ & $0.00 \%$ & $8.50 \%$ & $21.30 \%$ & $4.30 \%$ & $100.00 \%$ \\
\hline \multirow[t]{2}{*}{ Acute viral hepatitis } & Count & 0 & 6 & 4 & 0 & 1 & 0 & 0 & 11 \\
\hline & Percent & $0.00 \%$ & $54.50 \%$ & $36.40 \%$ & $0.00 \%$ & $9.10 \%$ & $0.00 \%$ & $0.00 \%$ & $100.00 \%$ \\
\hline \multirow{2}{*}{$\begin{array}{l}\text { Intra-abdominal } \\
\text { malignancies }\end{array}$} & Count & 0 & 20 & 13 & 1 & 10 & 14 & 1 & 59 \\
\hline & Percent & $0.00 \%$ & $33.90 \%$ & $22.00 \%$ & $1.70 \%$ & $16.90 \%$ & $23.70 \%$ & $1.70 \%$ & $100.00 \%$ \\
\hline \multirow{2}{*}{$\begin{array}{l}\text { Chronic Liver } \\
\text { Disease }\end{array}$} & Count & 3 & 147 & 103 & 4 & 79 & 47 & 2 & 385 \\
\hline & Percent & $0.80 \%$ & $38.20 \%$ & $26.80 \%$ & $1.00 \%$ & $20.50 \%$ & $12.20 \%$ & $0.50 \%$ & $100.00 \%$ \\
\hline \multirow[t]{2}{*}{ Diarrheal disease } & Count & 5 & 26 & 149 & 15 & 28 & 36 & 0 & 259 \\
\hline & Percent & $1.90 \%$ & $10.00 \%$ & $57.50 \%$ & $5.80 \%$ & $10.80 \%$ & $13.90 \%$ & $0.00 \%$ & $100.00 \%$ \\
\hline \multirow[t]{2}{*}{ HIV/AIDS } & Count & 0 & 1 & 9 & 1 & 6 & 5 & 0 & 22 \\
\hline & Percent & $0.00 \%$ & $4.50 \%$ & $40.90 \%$ & $4.50 \%$ & $27.30 \%$ & $22.70 \%$ & $0.00 \%$ & $100.00 \%$ \\
\hline \multirow[t]{2}{*}{ Septicemia } & Count & 1 & 4 & 6 & 0 & 2 & 8 & 0 & 21 \\
\hline & Percent & $4.80 \%$ & $19.00 \%$ & $28.60 \%$ & $0.00 \%$ & $9.50 \%$ & $38.10 \%$ & $0.00 \%$ & $100.00 \%$ \\
\hline \multirow[t]{2}{*}{ Upper GI bleeding } & Count & 0 & 4 & 3 & 0 & 2 & 1 & 0 & 10 \\
\hline & Percent & $0.00 \%$ & $40.00 \%$ & $30.00 \%$ & $0.00 \%$ & $20.00 \%$ & $10.00 \%$ & $0.00 \%$ & $100.00 \%$ \\
\hline Chi-square & \multicolumn{9}{|c|}{$X^{2}=471.050}$, \\
\hline
\end{tabular}

Our findings revealed that the rate of hospitalization within the five years under review was higher in our institution with a total number of 1266 cases when compared with other studies of similar duration from Nigeria. This may be explained by relative paucity and of health care facilities in the North-Western Nigeria compared to the Southern parts of the country resulting in overcrowding in the relatively fewer available hospitals. Seventy-two percent of the patients were admitted via Accident and Emergency (A\&E) unit. Many of the GIT diseases such as CLD and some forms of dyspepsia, are chronic in nature and tend to present with complications at the A\&E; the trends were higher in our study when compared with a report in Ido-Ekiti Nigeria[16].Another study conducted from the gastroenterologyout-patient clinic in the southern part of the countryby Oluwagbenga et al [17] documented 679 cases over similar period.Perhaps these variations occurred as a result of differences in watersanitation, hygiene and other environmental factors since majority of the diseases were communicable in nature. This study found a male to female ratio of 1.2:1; suggesting thatgenerally males suffer from gastrointestinal diseases more than females. Our finding is in agreement withthose of Oluwagbenga et al. [17]in Ado-Ekiti, Lesi et al.[6] in Lagos, Adeleye et al.[7] in Sagamu and Jemilohun et al.[8] inOgbomoso. They all had more males than females, with male to female ratios of 1.08:1, 1.17:1, 1.3: 1 and 1.4:1
In this study the mean age of presentation of the study participants was $39.4 \pm 18.4$, this was in line with what was documented byJemilohun et al.[] $38.9 \pm 18.39$. In contrast to other local studies, our report slightly differed from the findings by Adeleye et al[7], $42.0 \pm 15.50$ years and $43.8 \pm 16.32$ Oluwagbenga et al[17]

The 6 leading gastrointestinal diseases in this review were chronic liver disease, dyspepsia, diarrheal disease, abdominal $\mathrm{TB}$, intra-abdominal malignancies and cholecystitis.

Based on the findings from this study liver diseases accounted for $29.2 \%$. The high proportion could be due to the high endemicity of hepatitis B viral hepatitis in the region[ $\underline{18}$, 19] which is also a significant contributor to liver and bile duct cancers. Our finding differs from that reported by Adeleye et al in which chronic liver disease accounted for $12.4 \%$ of GIT diseases seen in their hospital [7].An estimated 3-4 million people are infected with hepatitis $\mathrm{C}$ virus (HCV) each year with a total of 130-170 million people chronically infected internationally[20].Dyspepsia was the second commonest gastrointestinal disease in our study and accounted for $19 \%$ of patients.Our finding is similar to that of Oguntoye et al. from South western Nigeria[17].However, Nwokediuko inEnugu, South-East Nigeria documented dyspepsia as being responsible for $81.9 \%$ of indications for upper GI endoscopy in South eastern Nigeria[21]. Various Hospital-based studies from Europe and the USA have 
showndyspepsia to be a leading cause of GI diseases[22-24].Hospital data depicting causes of morbidity and mortality are important parameters for confirmation of the geographical burden of disease and public health planning, involving programmatic needs, assessing and re-evaluation of health policies. In this study, the overall mortality due to GI diseases stood at $18.6 \%$. Among males, $24.6 \%$ of 688 died during the period of our study while a comparatively lower proportion of $11.6 \%$ among 578 females died within the same period. Mortality among men was much higher compared to female, majority of them presenting with terminal HBV related chronic liver diseases. Okoroiwu et al also from Nigeria, reported $8.3 \%$ of the overall mortality due to GI Diseases[25].

\section{CONCLUSION}

GIT diseases exert an enormous burden of morbidity and mortality on the North Western populations and urgent attention is required to mitigate further devastation. Majority of the GI diseases. Concerted efforts at improving water sanitation, hygiene coupled with health education and vaccination against hepatitis B Virus will go a long way to reduce this burden. Determination of the various GI disease conditions and the factors responsible for variability in incidence and outcomes of diseases will allow clinicians, public health professionals, policymakers, and healthcare organizations to intervene in a more logical way making effective use of resource allocation to decrease the overall burdenof gastrointestinal diseases.

\section{REFERENCES}

[1] Yamada T; Alpers DH; et al. (2009). Textbook of gastroenterology (5th ed.). Chichester, West Sussex: Blackwell Pub. pp. 2774-2784. ISBN 978-1-4051-6911-0.

[2] Perry AF, Dellon ES, Lund J, Crockett SD, McGowan CE, Bulsiewicz WJ, et al. Burden of gastrointestinal disease in the United States: 2012 Update. Gastroenterology. 2012;143:1179-1187.

[3] Bloom S, Webster G, Marks D. ed. Emergencies. In oxford handbook of gastroenterology and hepatology. 2nd edition. Oxford University Press. 2012;(Section 5):563-597.

[4] Everhart JE, Ruhl CE. Burden of digestive diseases in the United States part I: overall and upper gastrointestinal diseases. Gastroenterology 2009; 136: 376-386.

[5] Nwokediuko SC, Ijoma U, Obienu O, Picardo N. Time trends of upper gastrointestinal diseases in Nigeria. Annals of gastroenterology. 2012;25(1):52-6.

[6] Lesi OA, Adeleye OO, Odeghe EO, Owoseni O, Adeyemoye AA. Prospective analysis of Gastroenterology Out-Patient Consultations at the Lagos University Teaching Hospital, Nigeria. Niger J Gastroenterol Hepatol. 2013;5(1):21-27.

[7] Adeleye O, Olatunji A, Afe T, Odusan O, Olaitan A, Soyewo G. A study of disease pattern in a tertiary level Gastroenterology and Hepatology Out-Patient Unit. Annals of Health Research. 2017;3(2):92-97.

[8] Jemilohun AC, Akanbi OO, Oiwoh SO, Adeleke AA, Akanbi OA. Spectrum of Adult Digestive Diseases Presenting at a Suburban Tertiary Health Facility in Nigeria. Journal of Advances in Medicine and Medical Research. 2017;24(2):1-12.

[9] Adeole AA, Arowolo OA, Alatise OI, Osasan SA, Basiriye LA, Omoniyi EO, et al. Pattern of death in a Nigeria teaching hospital; 3 decade analysis. African Health Science. 2010; 10:266-272.

[10] Adetiyibi A, Akisanya JB, Onadeko BO. Analysis of the causes of death on the medical wards of the University College Hospital, Ibadan over a 14 year period (1960-1973). Trans R Soc Trop Med Hyg. 1976 70:466-473. https://doi.org/10.1016/0035-9203(76)90131-0 PMID: 841650 .
[11] Ayeni O. Causes of death in an African city. Afr J Med Sci. 1980; 9:130-147.

[12] Ogun SA, Adelowo OO, Familoni OB, Jaiyesimi AE, Fakoya EA Pattern and outcome of medical admissions at the Ogun State University Teaching Hospital Sagamu—A three year review. West Afr J Med. 2000; 19:304-308. PMID: 11391846.

[13] Adekunle O, Olatunde IO, Abdulateef RM. Causes and pattern of death in a tertiary health institution in southwest Nigeria. Niger Postgrad Med J. 2008; 15: 247-250. PMID: 19169342.

[14] Johansson E, Wardlaw T. Diarrhoea: Why children are still dying and what can be done, UNICEF/ World Health Organization, New York/Geneva. 2009.

[15] Asrani S, Devarbhavi H, Eaton J, Kamath P. Burden of Liver Diseases in the World. Journal of Hepatology. 2018;70.

[16] Oluwagbenga, O. O., \& Musah, Y. (2018). An 8-year retrospective review of gastrointestinal medical emergency conditions at a tertiary health facility in Nigeria. Sudan Journal of Medical Sciences (SJMS), 13(1), 1-11. https://doi.org/10.18502/sjms.v13i1.1684.

[17] Oguntoye Oluwatosin Oluwagbenga, Yusuf Musah1 OP, Soje Michael Osisiogu, Oguntoye Oluwafunmilayo Adenike, Oguntade Hameed Banjo, Ariyo Olumuyiwa Elijah, et al. Spectrum of Disease Conditions Seen at the Gastroenterology Clinic of a Tertiary Health Facility in South-Western Nigeria. Journal of Advances in Medicine and Medical Research. 2020;32(6):77-87.

[18] 18. A Yakubu,DM sahabi, A Umar,Y Saidu, UF Magaji. Prevalence of HBsAg Among Prospective Blood Donors and Pregnant Women in Kebbi State Nigeria. Nigerian journal of Basic and Applied Science. 2016; 24(1): 57-63.

[19] Musa BM, Bussell S, Borodo MM, Samaila AA, Femi OL. Prevalence of hepatitis B virus infection in Nigeria, 2000-2013: a systematic review and meta-analysis. Nigerian journal of clinical practice. 2015;18(2):163-172.

[20] Perz JF, Armstrong GL, Farrington LA, et al. The contributions of hepatitis $\mathrm{B}$ virus and hepatitis $\mathrm{C}$ virus infections to cirrhosis and primary liver cancer worldwide. J Hepatol 2006;45(4):529-38.

[21] Sylvester Chuks Nwokediuko, Uchenna Ijoma, Olive Obienu, Neri Picardo. Time trends of upper gastrointestinal diseases in Nigeria. Annals of gastroenterology. 2012;25:52-6.

[22] Perry AF, Dellon ES, Lund J, Crockett SD, McGowan CE, Bulsiewicz WJ, et al. Burden of gastrointestinal disease in the United States: 2012 Update. Gastroenterology. 2012;143:1179-1187.

[23] Russo MW, Wei JT, Thiny MT, Gangarosa LM, Brown A, Ringel Y, et al. Digestive and liver diseases statistics. Gastroenterology. 2004;126(5):1448-1453.

[24] 24. Shaheen NJ, Hansen RA, Morgan DR, Gangarosa LM, Ringel Y, Thiny MT, et al. The burden of gastrointestinal and liver diseases. Am J Gastroenterol. 2006; 101(9):2128-2138.

[25] Okoroiwu HU, Uchendu KI, Essien RA (2020) Causes of morbidity and mortality among patients admitted in a tertiary hospital in southern Nigeria: A 6 year evaluation. PLoS ONE 15(8): e0237313. https://doi.org/10.1371/journal. pone.0237313. 